States suggests that there are few penalties for introducing lead-free petrol. The added cost to the consumer in the first two or three years is probably no more than $£ 0.8$ pence a gallon, according to the UK Ministry of Transport, while the lobbyists claim that studies in the United States and Canada prove that there are definite savings in vehicle maintenance costs of perhaps \$0.05 a US gallon. In addition, European car manufacturers already make cars for the US and Japanese markets designed to run on lead-free petrol.

But industry is unlikely to be happy about being asked to make new investments when there is already a massive overcapacity in European refineries and the car industry is faced with a prolonged recession.

Their defence rests mainly on placing doubt on the scientific evidence of low concentrations of lead in air causing damage. While EEB and BEUC admit there is unlikely ever to be exact correlations between, for example a reduction of lead air concentration and the number of mentally subnormal children in the EEC, there is enough evidence to warrant action.

The Isotopic Lead Experiment being sponsored by the Commission in Turin and Piedmont indicates that at least 30 per cent of the lead in blood comes from petrol, although there are, of course, plenty of other sources such as paint or plumbing. In the experiment, lead from Broken Hill Mine in Australia with an easily recognizable mix of isotopes 206 and 207 was put in the petrol sold in the area between 1977 and 1979 thus enabling the source of the lead in blood to be immediately identified. The full report of the research has yet to be released on the grounds that there has been some difficulty in interpreting the data, but there are now rumours that the real reason is the alarming nature of the conclusions.

The arguments will undoubtedly continue, though, on what constitutes a safe level of exposure. This year EEC approved a directive for a maximum blood lead level of 60 microgrammes per decilitre in the workplace despite calls from the European Parliament and some member states for more stringent standards.

The European Commission wants to review the blood lead reference levels which are the criteria for assessing the need to take remedial action. The reference levels are a maximum of 20 microgrammes per decilitre of blood for 50 per cent of the population, 30 for 90 per cent and 35 for 98 per cent of the population.

The Lawther Report in the United Kingdom, published in 1980 , asserted that there was no convincing evidence of deleterious effects below the 35 microgrammes per decilitre level. Yet an American study by Davidow et al. in New York in 1982 on the influence of lead on the production of haemoglobin suggests that the blood lead level threshold below which children's haemoglobin production is not affected is 15-18 microgrammes per decilitre.

Jasper Becker

\title{
Blue skies all around
}

The pace of industrial investment in British academic research seems to be quickening. After several years of niggardly treatment at the hands of the British taxpayer, British academics appear to be more willing than ever that their research should be supported by industrial money. This is the spirit in which British Petroleum's Venture Research Unit, formed by BP Limited two years ago to support what is called "blue skies research", decided to invest $£ 500,000$ in four novel academic projects, three in Britain and one in Austin, Texas.

The four contracts agreed upon last week (but yet to be negotiated with the intended recipients) illustrate what $\mathrm{BP}$ means by blue skies research. One, with the University of Aberdeen, is an exploratory project further to investigate the possibility that L-phase bacteria may be able to transfer genetic material directly into the cells of plants.

The venture unit is also offering research contracts to the University of Sheffield to investigate the application of control engineering methods to the study of photosynthesis and to the University of Dundee for an investigation of the apparently superior properties of amorphous silicon as a material for semiconductors. The proposed contract with the University of Texas, Austin, is for the development of the work of Dr Jess Kimble on optically bistable devices, possible components in future computers.

Some of the score or so of projects so far backed are relevant to the immediate needs of BP, which maintains its own much larger in-house research programme for that purpose. According to Dr D.W. Braben, the manager of the venture unit, the objective is to find people who are preoccupied with some unusual problem and who appear to have the ingenuity to solve it. Many of the contracts so far signed are concerned with the mathematics of complex processes, with computer applications and with the behaviour of microorganisms. Under the usua! arrangement with an academic group, publication is allowed until commercial exploitation is foreseen.

The University of Sheffield is also the partner in another industrial venture announced this week - the founding of a company (Plant Science Ltd) to exploit several applications of plant science developed at the university's Institute of Biotechnology, founded with a grant from the Wolfson Foundation in 1978 and converted into an independent unit (with a further grant of $£ 360,000$ ) in March 1981.

The new company has been started with a capital contribution from TDC, described as "the high-technology arm" of Finance for Industry, a kind of merchant bank supported by various clearing banks. Among the objectives of Plant Science Ltd will be the development of plant varieties yielding substantial quantities of chemicals (such as steroids) and of processes for their extraction. The technical director of the new company is Dr Michael Fowler, from the university institute, who with Dr Anthony Jubb (recruited as managing director from ICI Ltd) will share part of the equity with TDC and the university.

\section{UK research councils}

\section{Spend, spend, spending}

Next to the cost of defence and of the police, the British science budget stands out in British public expenditure by having increased in the past three years even more quickly than the rate of inflation. Sir Alec Merrison, chairman of the Advisory Board for the Research Councils, said last week that "you cannot stay in that position without paying a price". Part of the price may be the publication last week of the board's advice on how to cut the cake ( $\$ 507$ million in 1983-84, 1.2 per cent more than needed to compensate for inflation).

The board has the following comments to make on the cases put to it by its pensioners, five research councils, the Royal Society and a museum.

The Agricultural Research Council (ARC) plans to maintain and even increase support for university research, especially in biotechnology, reproductive endocrinology, plant growth hormones and food process engineering. A new computer centre is planned. If there were more money (there is not) it would be spent on the genetic manipulation of animals, vaccine production and the micro-propagation of plants.

The board says that ARC should press ahead with its priority projects and should seek outside sources of financial support for some of this but recommends a constant cash contribution from the science budget in the next three years of $£ 46$ million. ARC's total income would increase from $£ 95.9$ million in the present financial year to $f 107$ million in $1985-86$ on the assumption that the agriculture ministry would pay more for commissioned research.

The Medical Research Council (MRC) plans a scheme to rescue biomedical research groups left stranded by university economics up to a total of 20 groups at a cost of $£ 50,000$ each in each of the next five years, and a modest increase of graduate student support. The council promises "major restructuring" at the National 